\title{
Coconut processing technologies for rural transformation - Case study on coconut water vinegar
}

\author{
Chapter · October 2010
}

DOI: $10.13140 / 2.1 .1805 .0887$

CITATIONS

0

3 authors, including:

\section{Seeja Thomachan}

Kerala Agricultural University

11 PUBLICATIONS 25 CITATIONS

SEE PROFILE
READS

2,025

Some of the authors of this publication are also working on these related projects:

Multiple correlates of obesity in school children View project

KSCSTE Young Investigators Programme in Biotechnlogy - Research Project - Accelerated breeding

Project for anthracnose resistance in vegetable cowpea through molecular marker assisted selection View project 


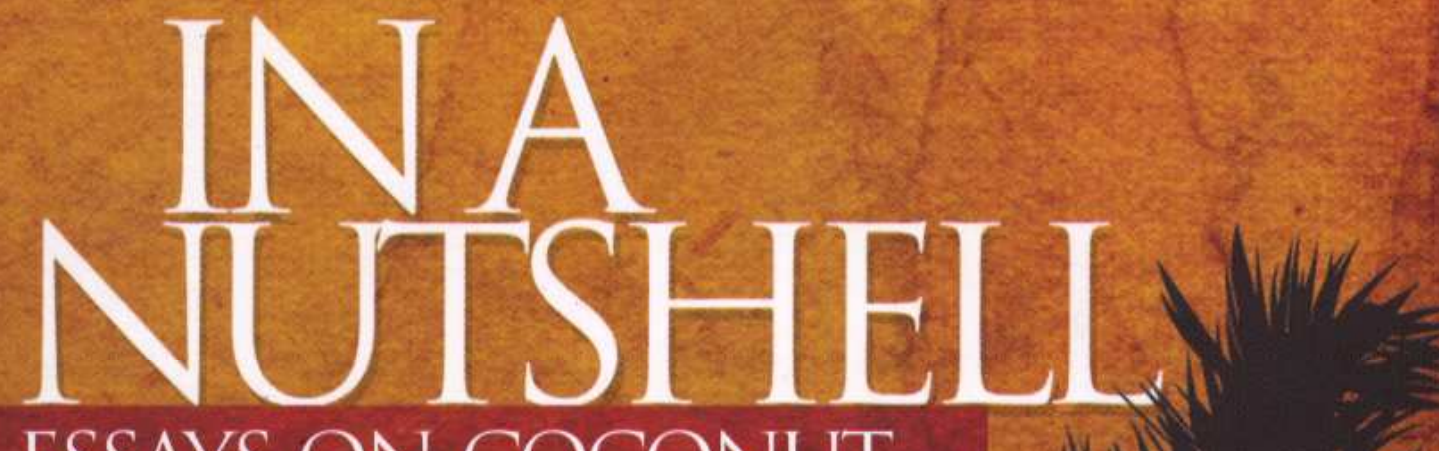
ESSAYS ON COCONUT
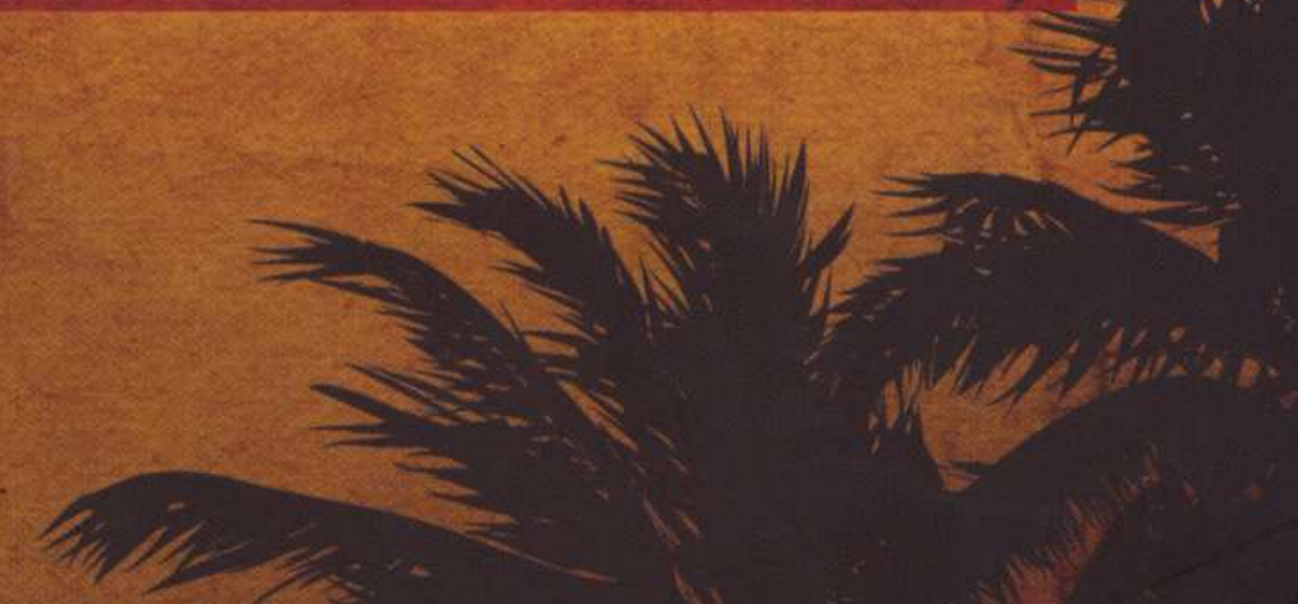

ED. Dr. C.V. Ananda Bose IAS 


\title{
In a Nutshell
}

Essays on Coconut

Published By:

\author{
Coconut Development Board \\ Ministry of Agriculture, Department of Agriculture and Co-operation, \\ Government of India \\ Kera Bhavan, Kochi - 682 011, India \\ E.mail : cdbkochi@gmail.com \\ cdbkochi@dataone.in
}




\title{
Coconut Processing Technologies for Rural Transformation - Case Study on Coconut Water Vinegar
}

\author{
Seeja Thomachan Panjikkaran $\nmid$, Deepu Mathew and Habeeburrahman P. V. \\ KVK - Malappuram, Kerala Agricultural University, Tavanur - 679 573, India \\ e-mail : seejathomachan@gmail.com
}

\section{Introduction}

In India coconut based economy depends mainly on a single product, coconut oil. To cope with the market instabilities, there is an urgent need for promoting alternative uses of coconut and its products for value addition. Coconut water wasted from copra processing units could effectively be utilized by converting its sugars to acetic acid ie., natural vinegar.

Vinegar is exclusively produced from starchy and/or sugary substrates by a double fermentation process, alcoholic followed by acetous fermentation. In the first stage sugar level of coconut water is raised to 12 per cent and further subjected to alcoholic fermentation by the action of yeast Saccharomyces cervisiae. The first stage fermentation yields 6 per cent ethyl alcohol and the second stage fermentation is facilitated by acetic acid bacteria, which converts alcohol to 6 per cent acetic acid that is natural vinegar. From time immemorial, vinegar was prepared in households using toddy. Coconut water vinegar production technology avoids wastage of coconut water and provides an additional source of income and employment for those involved in the copra processing sector.

The extension strategies adopted by Krishi Vigyan Kendra-Malappuram of Kerala Agricultural University have provided opportunities for additional income generation by women groups and unemployed youth in Malappuram district. Details on potential of this technology, dissemination strategies adopted and case studies are presented herewith.

\section{Methodology}

\section{(i) Background}

Coconut water vinegar production is based on two stage fermentation technique, developed by Coconut Development Board (CDB, 2005). A small-scale production unit based on CDB technology has been designed at KVK Malappuram to suit the requisite of around 25 litres per week that could be an adjunct to oil expelling or copra drier units. Technical as well as practical constraints that may emerge with the entrepreneurs were taken care of while designing the unit. Cost-benefit ratio was worked out by considering the recurring expenditure and depreciation on non-recurring expenditure. 


\section{(ii) Design of small-scale fermentation unit based on CDB Technology}

The coconut water output of an average copra processing unit in Malappuram district is around $100 \mathrm{~L} /$ day and hence a low cost small scale production unit of this size has been designed and used in the second stage of fermentation. The fermentation unit is made of food grade plastic container of $100 \mathrm{~L}$ capacity and used for producing $25 \mathrm{~L}$ of vinegar per week. Food Grade plastic (Type 1 plastic) lid for closing was purchased from the market. It is very important to check if the plastic is of Food Grade since the low grade plastics may impart a characteristic and unacceptable odour to the vinegar. The lid for closing the bucket has to be provided with maximum possible number of holes with a heated iron rod of about $3 \mathrm{~mm}$ diameter. More number of holes gives better result since the acetic acid bacteria is aerobic and facilitates the escape of released carbon dioxide during fermentation. This lid may always be kept covered with a muslin cloth to avoid the flies that get attracted. Acetic acid bacteria reside on the top most layer of the vinegar generator and this layer should not be disturbed on adding alcohol. Hence, a PVC inlet of half-inch diameter with a ' $U$ ' turn at the immersed end is provided for adding alcohol from the first stage. Alcohol:mother vinegar ratio at addition phase should be 1:3. An outlet for collecting vinegar was provided at a height of $40 \mathrm{~L}$, so that the top most bacterial layer is not destroyed.

\section{(iii) Technology dissemination at grass-root level}

The technology dissemination programme consisted of On Farm Trials (OFTs), Front Line Demonstrations (FLDs), trainings, seminars, farmers' interface, exhibitions, radio talks, popular articles (Panjikkaran, 2006, 2008a, 2008b) and extension bulletin (Panjikkaran, 2007). FLDs and OFTs were conducted among Self Help Groups (SHGs), Neighbourhood Groups (NHGs) and unemployed youth. As a continuation of this programme, technology on production of Nata-de-coco, a dessert item which can be prepared from vinegar was also popularized. The efficiency of the technology in rural transformation was quantified in terms of the number of entrepreneurs attracted by this technology every year. Follow up of the new units was done and the case studies are presented for better understanding of the potential of this technology. The strategies adopted by KVK Malappuram for the dissemination of this technology are detailed in Table 1.

\section{Installation}

The containers were procured on special order and assembled at KVK Malappuram. The beneficiaries for the FLDs and OFTs were identified with the help of Kudumbashree Mission and ATMA under the Department of Agriculture, Government of Kerala. The units were handed over to the SHGs or Kudumbashree units at the point of their operation and off-campus trainings were organized at the time of installation. Through OFTs and FLDs, KVK has installed 30 units in Malappuram district. Each unit consisted of food-grade plastic container (100 litre capacity), burette with stand, pipette $(1 \mathrm{ml})$, conical flask $(250 \mathrm{ml})$, measuring cylinder $(50 \mathrm{ml})$, glass funnel, 10 litres mother vinegar, $100 \mathrm{~g} \mathrm{NaOH}$, phenolphthalein, $100 \mathrm{~g}$ citric acid and $100 \mathrm{~g}$ ammonium sulphate. For the first three months, regular inspection was made in every unit to monitor the performance and to collect the 
feedback. The details regarding the recurring and non recurring expenditure for the installation of a coconut water vinegar unit as designed at KVK Malappuram are given in Table 2.

\section{Social Impact}

The unit enabled the entrepreneurs to initiate the production at a lower initial investment of Rs 3,900. The produce is pasteurized and marketed in sealed glass or plastic bottles at Rs. 50/litre and majority of the units are earning an average additional income of Rs 5,000/ month. The units are also supplying mother vinegar at the same price. Acidity of the product is determined using simple titration technique that is feasible at unit level.

The adoption of technology was more evident from FLDs and OFTs. Previous studies by Mathew and Habeeburrahman (2008) also support this fact since they found that On Farm Tests (OFTs) followed by Front Line Demonstrations (FLDs) are the most efficient techniques for diffusion of agricultural innovations at grass-root level. In this case, since the technology is already proven, FLDs are more suitable at farmers' level compared with OFTs. In both OFTs and FLDs the per cent of adoption was high but due to financial and operational difficulties, few units were closed. Presently, the active units are marketing their produce to pickle production units and restaurants. They also find market for their produce by participating in trade fairs, exhibitions, and door delivery. The following case studies are furnished to demonstrate the potential of this technology as recorded from the farmers of Malappuram district.

\section{Case Study-1}

Mrs. Sreelatha, President of Thulasi NHG group, Mathur, Malappuram district, is a primary school teacher. The group is active with copra drier unit, vinegar production unit, mushroom and pickling unit. The unit started functioning in the year 2006 with 15 members. The training and technical advice from KVK helped them in establishing these units. They are marketing their produce by participating in trade fairs, exhibitions and home to home delivery. They are using this vinegar in their pickle production unit. The unit produces around 120 litres/month and markets both mother vinegar and vinegar at the rate of Rs 50/L. They have already stepped in to Nata-de-coco production in four flavours (Strawberry, Pista, Pineapple and raw form).

\section{Case Study-2}

Mrs. Vanaja T.M., an active member of SHG group has started a coconut water vinegar production unit at Ayankalam, Ponnani Taluk, Malappuram District. She has started the unit by obtaining license from Tavanur Panchayath. The unit has started functioning from the year 2006. Vanaja participated in the vocational training on 'Profitable Agriculture related Enterprises for women' conducted at KVK. From the various trainings that she received, Vanaja selected vinegar production and is running the unit successfully. The unit is producing $100 \mathrm{~L}$ of vinegar/month and the product is mainly marketed in hoteis, bars and in exhibitions. 


\section{Case Study-3}

Mr. Sivadasan hailing from a poor family is engaged in dehusking of coconut as a means of livelihood. He approached KVK for training on coconut water vinegar and he is presently managing a unit successfully in association with his friends. The coconut water for vinegar production is collected free of cost locally and the output is around 175 litres/ month. This entrepreneur also possesses a biogas unit and states that coconut water is capable of increasing the rate of biogas production.

\section{Case Study-4}

Ms. Safeera, a plus two educated unemployed rural woman utilizes her free time by engaging in coconut water vinegar production. She hails from a poor family and her father is running a grocery shop. Vinegar produced is marketed through this grocery shop at a rate of Rs 40/ litre. She opined that majority of customers are unaware of the natural product and are not ready to pay a price higher than that of synthetic vinegar.. According to her, since coconut water is collected free of cost, selling the produce even at Rs $20 /$ litre will be profitable. Safeera is planning to extend her unit with one more production unit after obtaining loan and license from concerned authorities.

\section{Case Study-5}

Mr. K. T. Musthaffa, a rice and coconut farmer of Vettom panchayat, Tirur block of Malappuram district has started vinegar production after necessary training from KVK (Figure 7). Presently he is the largest producer in this district, 400 litres/month. The main outlet of marketing is trade fairs and exhibitions and he is planning for a large scale production after obtaining license from the Vettom panchayath. Presently he is marketing both vinegar and mother vinegar at Rs 50/ litre and has already started the production of Nata-de-Coco as an adjunct to vinegar production.

\section{Level of Adoption and Horizontal Spread of the Technology}

Small scale production of vinegar is gaining popularity in the district since it provides an additional source of income and could be started with low financial inputs. The steady increase in the number of units in Malappuram district is confirmatory to this. ICAR is presently funding for the transfer of this technology to the nearby districts also. The Front Line Demonstrations done by the Kerala Agricultural University in Thrissur and Palakkad districts have resulted in the acceptance of this technology by the local entrepreneurs. As a result 10 new units have come up in each of the districts. The Agricultural Technology Management Agency (ATMA) that is being implemented by the Department of Agriculture, Government of Kerala is also funding KVK Malappuram for assisting the entrepreneurs to set up vinegar units in the district.

\section{Feedback/ Problems Encountered}

Technical feedbacks are being regularly collected from farmers. The major problem faced by the units is the turbidity of the produce. Studies were conducted both at KVK lab 
and in 10 farmer units for solving this problem. The application of chitosan for rapid clarification of coconut water vinegar was found promising. Chitosan is a natural clarifying agent used in wine and juice industry for clarification of the product. Studies were conducted to standardize the amount of chitosan to be added and the best storage container (coloured/ transparent, glass/ plastic containers etc.). The indigenous technology for clarifying the natural vinegar is by the addition of dried chillies and this is an easier methodology feasible for small scale units in rural areas.

\section{Summary}

The Indian coconut sector is on a path of steady progress in terms of productivity and production and the scope for product diversification is enormous. The growing health consciousness and the preference for natural products could very well be exploited. A low cost small scale production unit that yields around 100 litres of coconut water vinegar per month, with an average acidity of $6.0 \%$, was designed at KVK Malappuram based on technology developed by Coconut Development Board. The technology was disseminated to the farmers of Malappuram district by Krishi Vigyan Kendra of Kerala Agricultural University through numerous on-campus and off-campus trainings, seminars and farmers' interface, Front Line Demonstrations (FLDs), On Farm Trials, exhibitions, radio talks, technical bulletins and popular articles. Presently, in Malappuram district alone, the technology is being continuously used by more than 25 beneficiaries of our extension programmes, ensuring additional income from coconut water that is otherwise wasted. Rural youth, women Self-help groups (SHGs), Neighbourhood groups (NHGs) and unemployed individuals are the main beneficiaries. The average monthly income of these SHGs through vinegar alone is around Rs. 5000 with about $100 \mathrm{~L} /$ month output. The success of the technology is once again evident with the spread and recent large scale adoption by farmers of few more districts such as Palakkad, Thrissur and Kollam. 
Table 1. Details regarding mode of dissemination of technology

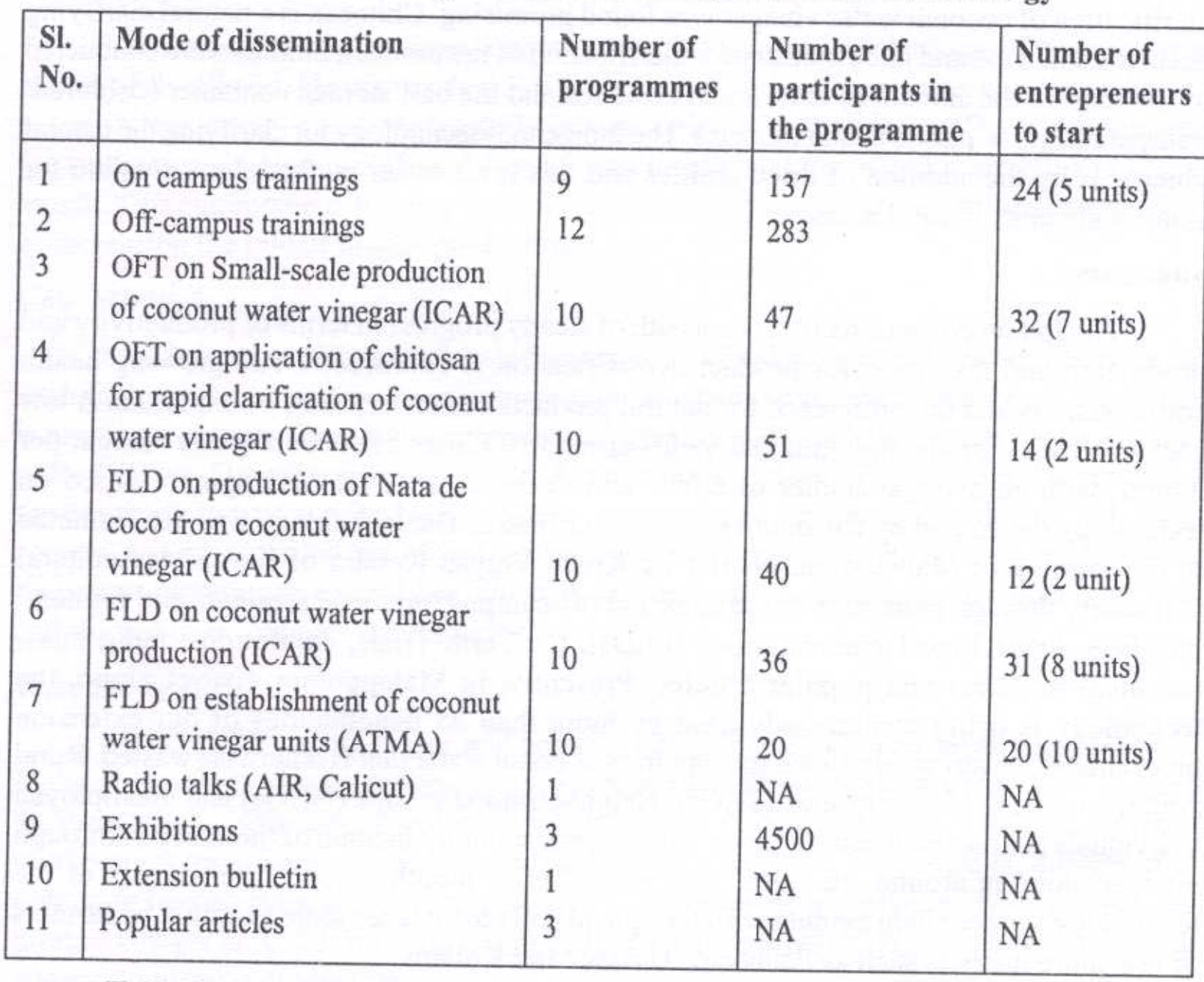

Table 2. Expenditure for setting up small scale vinegar production unit

\begin{tabular}{|c|c|}
\hline Expenditure & Amount (Rs) \\
\hline \multicolumn{2}{|l|}{ Non-recurring } \\
\hline 1. Food grade plastic container (100 litre capacity) & 450 \\
\hline 2. Burette with stand, pipette $(1 \mathrm{ml})$, conical flask $(250 \mathrm{ml})$, & \\
\hline measuring cylinder $(50 \mathrm{ml})$, funnel & 1500 \\
\hline 3. Mother vinegar & 1500 \\
\hline 4. Plastic items/ utensils & 250 \\
\hline Total & 3700 \\
\hline $\begin{array}{l}\text { Recurring }(0.1 \mathrm{~N} \mathrm{NaOH}, 1 \% \text { Phenolphthalein, citric acid } \\
(2 \mathrm{~g} / \text { litre), ammonium sulphate (1 } \mathrm{g} / \text { litre), sugar }(12 \%) \text {, yeast } \\
\text { (Saccharomyces cervisea } 1 \mathrm{~g} / \mathrm{ltre})\end{array}$ & 200 (for 25 litres) \\
\hline
\end{tabular}




\section{References}

CDB (Coconut Development Board). 2005. Naalikera vellathil ninnum vinaagiri, Technical Bulletin (Malayalam)

Mathew, D. and Habeeburrahrnan, P. V. 2008. A methodology for the quantitative assessment of the primary impact of agricultural technologies. Journal of Social Sciences 17: 293-299.

Panjikkaran, S. T. 2006, Vinegar from coconut water, toddy and cashew apple. Karshakashree. 12 (1): $72-74$.

Panjikkaran, S. T. 2007, Vinegar from Coconut Water, Krishi Vigyan Kendra - Malappuram, Kerala Agricultural University, pages 6.

Panjikkaran, S. T. 2008a, Efficient use of coconut water-Part I. Haritham, Deepika, dated 02.09.2008.

Panjikkaran, S. T. 2008b, Efficient use of coconut water-Part II. Haritham, Deepika, dated 08.09.2008. 